\title{
Tanggungjawab dan Pelaksanaan Zakat Kalangan Minoriti Muslim Thailand
}

\author{
Obligation and Implementation of Zakat among Muslim Minority in Thailand \\ WAEAMRENE WAEPA*, SHOFIAN AHMAD, MOHD.NASRAN MOHAMAD \\ \& MUHAMAD RAZAK IDRIS ${ }^{1}$
}

\begin{abstract}
Contributing zakat or alms is one of the most important Muslim obligations. This religious duty applied to all Muslims include those who live as a minority in a nonMuslim majority state. Muslim scholars such as Mahmud Shaltut, Yusuf alQaradawi and Zulfikar compare the obligation of contemporary Muslim minority with those in Mecca during the early period of Islam. They were required to give zakat although the method used is different compared to the Medinah period where they are a majority. This study suggests that contemporary Muslim minority in Thailand -in term of implementation-could use the methods applied to Muslim majority country. This suggestion is due to the special rights given to the Muslim community in Thailand compared to Muslim minority in other countries. Thai Muslims have a political and administrative rights which enable them to perform religious duties such as zakat which are guaranteed by the constitution of Thailand.
\end{abstract}

Keywords: alms giving, Muslim minority, Thailand, zakat

Tanggungjawab berzakat kalangan minoriti Muslim di Thailand masih menjadi persoalan terutama dari segi pensyariatan dan kaedah pelaksanaannya. Status minoriti Muslim telah menimbulkan persoalan tentang sejauhmanakah kewajipan berzakat itu perlu dilaksanakan. Penjelasan kedudukan minoriti dan tanggungjawab berzakat pada masa kini penting diberi huraian demi meningkatkan rasa tanggungjawab kalangan masyarakat seterusnya membolehkan zakat berfungsi sebagai instrumen penting pembangunan ummah serta dapat diterjemahkan secara berkesan dalam segenap segi kehidupan masyarakat Islam di Thailand hari ini.

\section{Minoriti Muslim di Thailand}

Keperluan kesedaran tentang tanggungjawab berzakat kalangan masyarakat Islam di Thailand hari ini bertambah penting memandangkan perkembangan penduduknya yang semakin bertambah dan berkembang pesat. Pada masa kini, masyarakat Islam di Thailand berstatus

\footnotetext{
1 Waeamrene Waepa*(Corresponding author), doctoral student at Department of Syariah, Faculty of Islamic Studies, Universiti Kebangsaan Malaysia, 43600 BANGI, Selangor, Malaysia; Shofian Ahmad, Ph.D., assoc. professor at Department of Syariah, Faculty of Islamic Studies, Universiti Kebangsaan Malaysia 43600 BANGI, Selangor, Malaysia, email: shofian@ukm.edu.my; Mohd Nasran Mohamad, Ph.D., professor at Department of Syariah, Faculty of Islamic Studies, Universiti Kebangsaan Malaysia, 43600 BANGI, Selangor, Malaysia, email: nasran@ukm.edu.my; Muhamad Razak Idris, Ph.D., senior lecturer at Department of Theology and Philosophy, Faculty of Islamic Studies, Universiti Kebangsaan Malaysia, 43600 BANGI, Selangor, Malaysia, email: mrazak@ukm.edu.my.
} 
minoriti dianggarkan sekitar 10 juta orang berbanding keseluruhan penduduk Thailand yang berjumlah lebih 70 juta orang. Kebanyakan masyarakat Muslim menetap di empat wilayah utama, iaitu Wilayah Narathiwat, Pattani, Yala dan Setul. Jumlah penduduk Muslim di kawasan ini sebanyak 4.2 juta orang. Majoriti masyarakat Muslim di Thailand berketurunan Melayu dan merupakan penduduk asal di empat wilayah tersebut.

Di samping empat wilayah utama itu, masyarakat Muslim juga menetap di wilayahwilayah lain seperti di Bangkok, Chiangmai dan Konken. Di Bangkok sahaja, terdapat satu juta orang penduduk Islam. Menurut Zahari (2014) perkembangan pesat masyarakat Muslim di Bangkok dan kawasan utara lain di Thailand hari ini didorong oleh faktor penghijrahan atas dorongan tuntutan pekerjaan, perkahwinan dan pendidikan.

\section{Minoriti Muslim dan Kewajipan Berzakat}

Sebagai penganut beragama Islam, salah satu kewajipan yang mesti disempurnakan masyarakat Islam Thailand ialah tanggungjawab berzakat. Zakat merupakan salah satu dari lima rukun Islam yang telah disyariatkan Allah (s.w.t.) ke atas hamba-Nya yang telah memenuhi syarat iaitu jumlah harta samada yang tersimpan atau yang dilaburkan dan memilikinya dalam tempoh yang tertentu. Dari segi teori, terdapat dua jenis zakat yang disyariatkan Allah kepada umat Islam iaitu zakat harta dan zakat fitrah. Zakat harta telah disyariatkan secara ikthtiar (pilihan) semenjak permulaan Islam iaitu pada zaman awal pembentukan masyarakat Islam di Mekah. Pada era itu, kadar dan jenis harta zakat belum ditentukan tetapi ditunaikan atas kesedaran para pembayar zakat (muzaki) itu sendiri.

Banyak dalil pensyariatan zakat ke atas umat Islam di dalam al-Quran. Antaranya firman Allah dalam al-Mu'minun (23:4) yang bermaksud:

Sesungguhnya berjayalah orang-orang yang beriman, iaitu orang yang khusyu' dalam sembahyangnya, dan mereka yang menjauhkan diri dari perbuatan dan perkataan yang sia-sia; dan mereka yang berusaha membersihkan zakat hartanya (dengan menunaikan zakat harta itu).

Dalam Surah al-Naml (19:3), firman Allah yang bermaksud:

Iaitu mereka yang tetap mendirikan sembahyang dan memberikan zakat, sedang mereka pula percaya dengan yakin akan hari akhirat.

Berpandukan ayat-ayat tersebut, jelas berzakat adalah satu tangungjawab yang diperintahkan Allah kepada seluruh penganut ajaran Islam. Zakat ialah satu ibadah yang dilaksanakan dengan penuh kesedaran oleh setiap orang yang beriman dengan ajaran agama Islam.

Jelas, seluruh umat Islam berkewajipan menunaikan zakat termasuk ke atas golongan yang dikenali sebagai minoriti Muslim hari ini. Ramai para sarjana Muslim membincangkan tentang kewajipan zakat ini, antaranya ialah Mahmud Shaltut (2001) yang menyatakan "alzakat rukun diniy 'am", bermaksud zakat adalah rukun agama yang universal. Beliau menjelaskan, 'Sekalipun kita berkeyakinan bahawa perzedaan pendapat dalam Islam menujukkan masalah berzakat dalam menerapkan kewajipan zakat itu begitu luas sebagaimana dapat kita lihat dalam kitab-kitab fiqh, namun begitu menurut hukum fiqh, orang Islam wajib mengeluarkan zakat apabila cukup syaratnya tanpa membezakan sama ada mereka adalah minoriti ataupun majoriti Muslim. Huraian ini menunjukkan seluruh umat Islam adalah wajib menunaikan zakat apabila syarat-syaratnya telah dipenuhi tanpa mengira kedudukan atau statusnya dalam sesebuah negara. 
Dalam perbincangan yang sama oleh Yusuf al-Qaradawi (2010), beliau membahagikan perintah berzakat kepada dua tempoh masa iaitu pertama, perintah zakat semasa di Mekah yang tidak terikat dengan peraturan dan undang-undang Islam; dan kedua, perintah berzakat yang diwajibkan semasa di era Madinah.

Pembahagian dua tempoh masa ini penting kerana ia menunjukkan perbezaan bentuk pelaksanaan kewajipan berzakat. Namun, dari segi pensyariatan berzakat, kewajipannya adalah tetap ke atas seluruh masyarakat Muslim.

Namun begitu, menurut Yusuf al-Qaradawi (2010) terdapat perbezaan dari segi pelaksanaan zakat. Sebagaimana termaktub di dalam surah-surah yang diturunkan di Mekah, pelaksanaan zakat itu tidak sama dengan ayat-ayat diturun di Madinah. Di Mekah, pelaksanaannya adalah berbentuk umum tanpa peraturan tetap berbanding di Madinah di mana pelaksanan zakat hendaklah mengikut had nisab dan besarnya jumlah yang telah ditentukan secara terperinci. Pelaksanaan zakat di era Mekah terbuka iaitu tidak ditentukan kadar dan nisab, tetapi diserahkan kepada kesanggupan individu Muslim melaksanakannya berpandukan keimanan, kemurahan hati dan rasa tanggungjawab terhadap masyarakat yang fakir miskin walaupun jumlahnya dalam kadar yang sedikit.

Pembahagian dua tempoh kefardhuan berzakat oleh Yusuf al-Qaradawi ini berpandukan

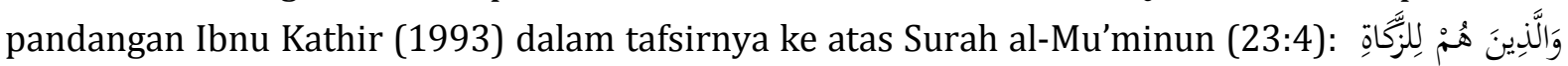
فَاعِلُونَ , beliau menyatakan, kebanyakan ahli tafsir berpendapat yang dimaksudkan dengan zakat di sini adalah zakat kekayaan, walaupun ayat itu diturunkan di Mekah. Perintah berzakat ini kemudiannya diwajibkan juga di Madinah pada tahun 2 Hijrah.

Fakta menunjukkan zakat yang diwajibkan di Madinah adalah yang mempunyai nisab dan kadar jumlah tertentu. Hal ini kerana di Madinah, masyarakat Islam telah memiliki daerah dan pemerintahan sendiri. Oleh itu, tanggungjawab mereka mengambil bentuk baru sesuai dengan perkembangan dalam bentuk hukum-hukum yang tersusun dan tidak lagi berasaskan gesaan, pesan dan anjuran sebagaimana di Mekah. Penerapan kewajipan zakat di Madinah memerlukan kekuasaan di samping didasarkan atas perasaan iman terhadap perintah tersebut. Ia juga melibatkan penelitian terhadap bentuk kekayaan yang harus dikeluarkan zakatnya, syarat bagi golongan yang wajib menyempurnakannya, sasaran-sasaran pengeluarannya dan badan yang bertugas mengaturkan dan mengelolanya.

Pandangan Mahmud Shaltut dan Yusuf al-Qaradawi itu juga sejajar dengan pendapat Zulfiqar (1996) yang menyatakan pensyariatan zakat telah berlaku sejak zaman Nabi Muhammad (s.a.w.) ketika Baginda berada di Mekah lagi. Ini dibuktikan dengan beberapa penurunan ayat Makkiyah berkaitan zakat yang tidak dinyatakan secara tunggal, malah ia digabungkan bersama perlaksanaan solat seperti firman Allah dalam Surah al-Mu'minun (23:4).

Ia adalah antara ayat-ayat Makkiyah yang diturunkan kepada Nabi Muhammad (s.a.w.) dalam mensyariatkan solat dan zakat. Namun begitu, keseluruhan ayat Makkiyah pada peringkat ini bersifat umum dan bebas dari segala bentuk ketetapan dan syaratnya, bahkan ia bergantung kepada tahap keimanan seseorang individu Muslim itu dalam mendapatkan bahagian di akhirat di samping rasa tanggungjawab dalam membantu saudara seislam yang memerlukan. Bahkan, amalan menunaikan zakat dipandang sebagai perbuatan yang terpuji dan merupakan ciri-ciri orang yang beramal soleh.

Perintah umum kewajipan berzakat ini sesuai dengan keadaan di Mekah di mana agama Islam ketika itu belum tersebar luas dan umat Islam merupakan golongan minoriti yang sering tertindas oleh majoriti kafir Quraish. Selain itu, perintah ini adalah salah satu cara mendidik orang Islam supaya mentaati perintah Allah (s.w.t.) secara berperingkat.

Di zaman Madinah, masyarakat Islam telah pun kukuh kedudukannya serta memilik wilayah sendiri. Nabi Muhammad (s.a.w.) terus menyampaikan risalah Allah dengan lebih sistematik demi kesatuan politik dan ummah yang telah terbentuk di Madinah. Ayat-ayat Madaniyah berkenaan zakat juga telah mula diperincikan dengan jelas dari masa ke semasa, 
termasuklah tentang jenis harta yang diwajabkan zakat, syarat wajib zakat, kadar tertentu yang membolehkan seseorang mengeluarkan zakat, kaedah agihan zakat dan institusi yang menguruskan hal ehwal zakat (Zulfiqar 1996).

Perbahasan tentang konteks kewajipan dan pelaksanaan berzakat yang dibahagikan kepada keadaan di Mekah dan Madinah oleh para sarjana Muslim menjadi asas penting terutama dalam menentukan kedudukan dan kewajipan minoriti Muslim dalam menjalankan kewajipan perintah berzakat. Jelas, keadaan kehidupan masyarakat Islam di Mekah boleh diqiyaskan atau dibandingkan dengan konteks kehidupan minoriti Muslim pada hari ini. Manakala, keadaan di Madinah merujuk kepada kehidupan umat Islam sebagai golongan majoriti dalam sesebuah negara.

Namun, apa yang pasti dari perbahasan tentang pensyariatan perintah zakat itu, seluruh umat Islam adalah bertanggungjawab menunaikan zakat apabila mencukupi syaratnya sama ada mereka tergolong sebagai majoriti atau minoriti Muslim. Perintah tersebut tidak membatasi keadaan statusnya tetapi dari segi bentuk pelaksanaannya, terdapat perbezaan bergantung kepada konteks atau situasi yang dialami oleh umat Islam. Dalam ertikata lain, peraturan pelaksanaan zakat ke atas minoriti Muslim longgar berbanding ke atas masyarakat Islam yang majoriti.

\section{Pelaksanaan Kewajipan Berzakat ke atas Minoriti Muslim Thailand}

Berpandukan perbincangan tentang kewajipan berzakat di atas, kewajipan berzakat ke atas minoriti Muslim di Thailand boleh dipecahkan kepada dua aspek iaitu pensyariatan dan pelaksanaan. Dari aspek pensyariatan, jelas kewajipan berzakat adalah satu tanggungjawab yang wajib ke atas masyarakat Islam Thailand. Ini berpandukan kepada kaedah qiyas kedudukan mereka dengan masyarakat minoriti Muslim di Mekah. Jumlah penduduk yang kecil dan keadaan kekuasaan pemerintahan yang terhad tidak membataskan tanggungjawab berzakat sebagai fardu agama.

Aspek kedua dari segi pelaksanaan zakat pula, kelihatan kedudukan kehidupan minoriti masyarakat Muslim di Thailand hari ini tidak boleh diqiyaskan dengan keadaan kehidupan masyarakat Islam di Mekah pada masa lalu. Masyarakat minoriti Muslim di Thailand hari ini memiliki beberapa hak yang khusus dan luas bagi menjalankan tanggungjawab agama berbanding masyarakat Islam di Mekah pada masa lalu yang terhad. Situasi kehidupan yang berbeza antara lokasi dan sejarah antara minoriti Muslim di Mekah dan Thailand menuntut satu kaedah pelaksanaan berlainan dilaksanakan oleh masyarakat Muslim di Thailand pada hari ini.

Kajian ini menganjurkan pelaksanaan kewajipan berzakat di Thailand hendaklah berpandukan qiyas dengan masyarakat Islam di Madinah. Ini berasaskan pada kedudukan minoriti Muslim Thailand hari ini memiliki kelebihan tersendiri yang membolehkan mereka menjalankan tanggungjawab berzakat sebagaimana masyarakat Madinah. Kajian ini mendapati, kelebihan ini melayakkan mereka untuk melaksanakan kewajipan mengikut keadaan kehidupan masyarakat Muslim yang berstatus majoriti.

Pandangan ini adalah bersandarkan juga dengan beberapa pendapat misalnya oleh Abdullah Nunsuk dan Harun Bengshun (2016) yang menyatakan pensyariatkan berzakat ke atas minoriti Muslim di Thailand adalah wajib dan pelaksanaannya hendaklah seperti dilaksanakan di negara majoriti Muslim disebabkan oleh beberapa faktor, antara yang utama ialah keterbukaan kerajaan Thailand dalam memberi kebebasan beragama dan tidak memberi gangguan kepada mana-mana pihak untuk mengamal Islam.

Pandangan yang sama dikongsi oleh Ismail Ali (2016) yang mengatakan kedudukan minoriti Muslim di Thailand berbeza sekiranya dibandingkan dengan negara minoriti yang lain seperti Burma dan Filipina. Sumbangan dan penyertaan ulama Islam dalam pembangunan negara Thailand bermula sejak awal. Misalnya, pusat pentadbiran urusan hal ehwal masyarakat Muslim telah ditubuh di Bangkok hampir lima ratus tahun yang dahulu. Penglibatan ini 
menunjukkan wujud pengiktirafan khusus ke atas minoriti Muslim Islam Thailand dari segi hak beragama. Status mereka sebagai minoriti terhad pada maksud jumlah penduduknya yang kecil berbanding penganut beragama Buddha. Ia tidak merujuk dari segi ketiadaan hak kebebasan menjalankan rukun agama yang menjadi kewajipan ke atas umat Islam.

Hak-hak dalam menjalankan kewajipan agama ke atas masyarakat Islam Thailand hari ini adalah jelas sekiranya ditinjau dari segi politik dan perlembagaan negara. Bersandarkan kepada perlembagaan Thailand yang dikenali 'Ratthamnun Haeng Ratanacati' (The Constitution of the Kingdom of Thailand) yang merupakan sebuah undang-undang tertinggi dan menjadi sumber perundangan dan pentadbiran segala urusan rakyat Thailand keseluruhan, ia memberikan kebebasan penuh kepada rakyatnya dalam beragama, bermazhab atau berideologi. Ini dapat dilihat pada perlembagaan dalam Fasal 37 yang menyatakan bahawa:

Setiap orang diberi kebabasan penuh dalam, beragama, bermazhab atau berideologi dan diberi kebabasan dalam melaksanakan amalan agama menurut mazhab atau ideologi yang dianuti selama mana tidak bertentangan dengan hak kewajipan kerakyatan dan tidak bercanggah dengan keselamatan negara dan moral baik bagi kerakyatan (Perlembagaan Negara Thailand, 24 Ogos 2007).

Berpandukan kepada hak-hak perlembagaan itu, masyarakat Muslim di Thailand bebas menunaikan kewajipan berzakat berasaskan ajaran agama Islam. Manakala dari segi kesediaan pentadbiran bagi pentadbiran zakat, masyarakat Islam di Thailand memiliki keistimewaan yang tersendiri berbanding kebanyakan minoriti Islam lain. Pada hari ini, hal ehwal keagamaan masyarakat Islam di Thailand secara rasmi ditadbir oleh badan yang dikenali Majlis Agama Islam yang kini wujud di 39 buah wilayah. Majlis Agama Islam ini diakui kewibawaannya oleh kerajaan dan perlembagaan negara. Berasaskan Akta Pentadbiran Islam (Artikel 17), memperuntukkan Ahli Jawantankuasa Islam Pusat yang diketuai oleh kesemua Majlis Agama Islam ini bergabung di peringkat kebangsaan dan memilih Jawatankuasa Pusat serta seorang ketua yang dinamakan Chalaratmontri atau Mufti Negara secara demokratik. Jawatankuasa Pusat ini menyelia Jawatankuasa Majlis Agama Islam Wilayah serta Jawatankuasa Agama Masjid di seluruh peringkat daerah di Thailand.

Menurut Pejabat Majlis Shaiyk Islam (2002), struktur pentadbiran Islam ini yang telah tersusun adalah berpandukan perintah Rama 9 pada 5 November 1997. Akta Pentadbiran Islam, Artikel 16 dan Artikel 19 juga menyatakan Jawatankuasa Islam Pusat terdiri daripada 44 orang, iaitu 33 orang dari wakil wilayah dan 11 orang dilantik oleh Chularatmontri. Majlis Agama Islam Pusat dan Majlis Agama Wilayah dipertanggungjawabkan mengendalikan hal ehwal kepentingan umat Islam termasuk berkaitan peribadatan, zakat dan persijilan halal. Dari segi kuasa pula, Jawatankuasa Islam berperanan sebagai penasihat kaepada Kementerian Dalam Negeri dan Kementerian Pendidikan.

Sistem dan struktur pentadbiran agama Islam di Thailand adalah satu kelebihan bagi masyarakat Islam di Thailand melaksanakan urusan keagamaan terutama dalam aspek kewajipan berzakat secara sempurna. Berasaskan kelebihan-kelebihan yang dimiliki dari segi hak politik, perlembagaan dan pentadbiran Islam, kedudukan minoriti Muslim di Thailand berpeluang untuk melaksanakan tanggungjawab berzakat sebagaimana peraturan yang dikenakan ke atas umat Islam yang berstatus majoriti sebagaimana perintah berzakat ke atas penduduk Madinah.

Kaedah dan peraturan tetap serta tersusun hendaklah disusun dan digerakkan bagi memanafaat kelebihan yang dimiliki minoriti Muslim Thailand hari ini bagi memperkasakan pembangunan institusi pengurusan zakat seterusnya memastikannya berkesan sebagai instrumen pembangunan ekonomi ummah.

Kesedaran beragama kalangan masyarakat Islam di Thailand hari ini hendaklah dijadikan kesempatan bagi membangunkan kaedah pelaksanaan terbaik dalam aspek 
pengurusan zakat. Pensyariatan zakat yang jelas dan difahami secara meluas hari ini adalah satu kekuatan bagi memastikan penglibatan masyarakat Islam yang menyeluruh dalam proses pembangunan ekonomi ummah menerusi keadah zakat.

\section{References}

Abdullah Basmeih. 2001. Tafsir Pimpinan Ar-Rahman kepada Pengertian al-Qur'an. Kuala Lumpur: Darulfikri.

Abdullah Nunsuk \& Harun Bengshun. 2016. Pengurusan Zakat di Kalangan Minoriti Muslim di Bangkok. Narathiwat, Thailand. 17 August. Interview.

Ibn Kathir, Abu al-Fida Isma'il. 1993. Tafsir al-Quran al-'Azim. Jil. 3. Cairo: Maktabah al-Khimat.

Ismail Ali. 2016. Pengurusan Zakat di Kalangan Minoriti Muslim di Bangkok. Narathiwat, Thailand. 5 August. Interview.

Pejabat Majlis Shaiyk Islam. 2002. Samnak Chularatmontri, Kammakan Klang Islam Haang Prathet Thai Laah Kammakan Islam Pracham Changwat, Akhbar Majlis Shaiyk Islam Bangkok Thailand. www.mind.fulnews.net/2016/04/04-18.html.

Perlembagaan Negara Thailand. 2007. https.//th,wikisource.org/wiki Ratthamanun Haeng Ratanati thai_250 Muat 3.

al-Qaradawi, Yusuf. 2010, Hukum Zakat Studi Komparatif Mangenai Status dan Falsafat Zakat Berdasarkan Quran dan Hadis. Transl. Indonesia: Mitra Kerjaya.

Shaltut, Mahmud. 2001. Al-Islam 'Aqidah wa Syari'ah. Cairo: Dar al-Shuruq.

Zahari Awang. 2014. Melayu dan Nusantara Kajayaan Lampau Kini dan Esok. Kelantan: Darulnaim Sdn. Bhd.

Zulfiqar. 1996. Zakat according to the Quran and Sunnah a Comprehensive Study of Zakat in Modern Perspective. Riyadh: Darul Salam. 